\title{
The Activity Model of Moderate Time, More Learning for Learning and Teaching Management in Basic Education
}

\author{
Suddhipong Srivichai ${ }^{1}$, Phramaha Sombat Dhanapanno ${ }^{2}$, Sin Ngamprakhon $^{3}$, \\ Phrakrubhattaradhammakhun ${ }^{4}$ \\ ${ }^{1,2,3,4}$ Faculty of Education, Mahachulalongkornrajavidyalaya University \\ Email: ${ }^{1}$ chaibie2529@ hotmail.com, ${ }^{2}$ sombat.cha@mcu.ac.th, ${ }^{3}$ sin.ngm@mcu.ac.th ${ }^{4}$ surachaihongtrakool@gmail.com
}

\begin{abstract}
The purposes of this research were; 1 . to study the activity model for Moderate Class, More Learning of basic educational students according to the state policy, 2. to develop activities for Moderate Class, and 3. to create activity sets for Moderate Class. The data were collected by questionnaires from 254 students and by in-depth interviews with 10 school administrators. The Results of the Study found that: 1 . The activity model for Moderate Class, namely; Part 1: Lead consisting of 1) Environment, 2) Principles of policy and theory of Moderate Class, More Learning, and 3) Objectives, Part 2: Model consisting of 1) Work system for information technology concerning students' skills, interest, and need for using in setting plans, 2) Management process consisting of four learning domains; Head, Heart, Hand, and Health, and Part 3: Implementation consisting of 1) Structure, 2) Decision of school administrators, 3) Evaluation guideline and achievement conditions depending on each school.2. The development of activities for Moderate Class, More Learning of basic educational students according to the state policy consisted of 4 activity groups and was to integrate students' learning, living and working together with 4 Hs; Head, Heart, Hand, and Health. 3. The four sets of activities were; Activity set 1: Learning management consisted of 2 sub-activities; story telling and match making. Activity set 2: Competency and learning enhancement consisted of 2 sub-activities; junior scientist and fun mathematics. Activity set 3: Characteristics and value enhancement consisted of 2 sub-activities; history through movies and religious conservation, and set 4: Characteristics and value enhancement consisted of 2 sub-activities; aerobics dance and organic agriculture.
\end{abstract}

Keywords

Activities Model, Moderate Time, Learning and Teaching

Article Received: 10 August 2020, Revised: 25 October 2020, Accepted: 18 November 2020

\section{Introduction}

In teaching and learning in educational institutions, young people have many learning and teaching problems in the classroom. Many children are assigned to do their homework. This caused a lot of stress in their learning. For 2 months, 3,831 schools under the Ministry of Education piloted the activity called "Reduce the time to learn, increase the time to learn" by the school reducing the academic time in the classroom. At around 2:00 p.m., the schools organize child development activities according to the age range under the $4 \mathrm{Hs}$ : Head (brain), Heart (mind), Hands (action) and Health (health).

The Office of the Basic Education Commission (OBEC) allocated 300 menus from 4 activities: skills building activities, free activities, vocational teaching activities and academic teaching activities. The first three weeks after the activity has been adapted according to the context of each school, OBEC summarizes operational results and reports to General Daowpong. $75 \%$ is satisfaction rating amid scholars' skepticism that it might be too early or not to assess satisfaction.[1]

"From inquiries, it was found that School administrators have to clarify and create knowledge and understanding for teachers many times, but they still do not understand as expected because this is a new policy. Many schools run the program without confidence about the outcome. Not clear in the course of action, the school administrators, teachers and parents are concerned about teaching in the core subject matter. They are afraid that the children will not receive the knowledge of the core course and result in decreased academic performance, especially at the secondary level where the teachers themselves have workloads and other activities either received from the central or various departments came in and overshadowed a lot of teaching time before.

That causes some teachers to think that it increases their workload. For example, opportunity expansion schools need to adjust the study time earlier and faster causing some children living far away to reach school on time or some schools schedule classes in the lunch time. While the smaller schools are getting material costs for organizing activities, but there is not enough. They must receive support from parents, students, temples, sub-district administrative organizations (SAO) and communities.

Nowadays, the transformation from the world society is moving into a learning society all the time in order to adapt and keep pace with the rapidly changing economic, social, political and cultural aspects of countries, such as hemispherical powers. Western and Eastern Hemisphere countries and neighboring countries of Thailand aim to revise education as a learning society in order to organize appropriate and quality education systems and processes, which are important mechanisms for improving population quality, quality of life and quality of the competition [2] Concrete Reform Guidelines One of the government's policies is to reduce academic school hours but not affect the core content that children should learn. Teachers must use their ability to design learning for their students to know more with effectiveness. According to the policy, the school hours have been put into practice by requiring the study in the academic subjects until 2:30 PM, but the time when the 
school quits remains the same as prior schedule, usually in the afternoon at 4.00 p.m.

Therefore, during the school period until the time when students return home, the schools have to organize creative activities for students to practice and should be a variety of activities that enhance their analytical thinking skills. And most importantly, there should be activities that encourage children to explore their own potentials and preferences. [3] It is believed that every child is unique and has their own abilities. The organization of activities does not have to be open to just the same room or level and known how to adapt, to help and take care of each other, interacting with people of various ages by simulating the real situation in society for children to learn, which will further enhance solving problem skills for Thai children. [4]

Moderate the study time, increasing the time of knowledge is the educational vision framework to prepare students for the 21 st century learning in Thailand. It is in line with many of the world's educational leaders who agree with the concept as most important in the 21stcentury: knowledge of the world, basic knowledge of occupation, basic knowledge of citizenship, health and environment, and essential skills in the 21 st century including learning and innovation skills, information, media and technology skills, work skills, practical life skills (with families, schools, communities, states, and nations). While the world is changing, only people who have the knowledge and skills to cope with constant change and who can adapt themselves to new situations will be successful. Throughout the 21st century, students will be able to learn and adapt to change over time. [5]

Therefore, the researcher is interested in studying how timeconsuming education is essential to how reducing learning time increases learning time can improve teaching and learning in different classes and how the results should be assessed, reducing study time should be increased learning time for teaching and learning activities, and how much reduction of study time increases the learning time in the direction of the objective setting.

\section{Research Objectives}

1. To study the format of activities to reduce the study time, increase the learning time of basic education students according to government policy,

2. To develop activities to reduce the study time, increase the learning time of basic education students according to government policy, and

3. To create a series of activities to reduce the study time, increase the knowledge time of basic education students according to government policy.

\section{Research Methods}

\section{A. Research Methods}

This research study was a qualitative study, by dividing the research scope as follows:

1) Content focus on education, a study of activities arrangement, reducing learning time, increasing learning time for teachers and basic students according to the policy of the government of educational service area, Bangkok
2) Population of 120 administrators and teachers and 254 of 740 primary school students in grades 4-6 responded to a questionnaire as the samples.

\section{B. Research Process}

Researchers will perform as follows:

1) Studying the principles, concepts and theories on learning time reduction and learning time for teaching and learning at the basic education level.

2) The research instruments were student questionnaires and interviews with administrators and teachers.

\section{Research Results.}

5.1 The results of the study, the format of the activities to moderate time, increase the learning time of the students at the basic education level according to the government policy, found that the opinions of all four aspects of students were at a high level, namely

Part1: Learning management; there is a high level of overall practice, students learn to coexist, considerate and help each other. Students learn and practice happily and can develop their own abilities.

Part 2: Enhancing competencies and learning; there was a high level of overall practice, including activity patterns that meet the needs of students. The media / materials used for the activity are appropriate.

Part 3: Strengthen characters and values; there was a high level of overall practice, including activities to cultivate students to become more patriotic, religious and monarchical. The students enjoyed the activities, and organizing activities was essential to the daily life of the students.

Part 4: Enhance working, living and life skills; the overall practice level was at a high level, including interest response activities, aptitude, student life promotion activities, and activities that meet the needs of learners according to their differences.

5.2 Develop activities to reduce learning time and increase learning time of primary school students.

Step 1: The learning management was that;

1) Students learn about coexistence, generosity and help.

2) The students learned happily.

3) Students have practiced and developed their own abilities

4) Complete the integration of 4 Hs: Head, Heart, Hand, and Health

5) Provide integrated learning to complete all $4 \mathrm{Hs}$ to jointly develop continuous learning, know how to practice teamwork skills, able to manage knowledge in daily life, and be kind to friends and society

6) Activities to moderate the learning time and increase the time of knowledge of the Office of the Basic Education Commission has established 4 sections, 16 groups. The four sections are 1) learner development activities, 2) capacity and learning activities, 3) enhancing characteristics and values, and 4) getting work, livelihood and life skills.

Step 2: Enhances competence and learning, namely

1) Activity patterns to meet the needs of students,

2) The media / materials used in the activity are appropriate,

3) The duration of the activity is appropriate,

4) The school focuses on organizing activities to enhance competencies in 5 areas, namely communication, thinking 
development, problem solving, use of technology, and life skills development,

5) Activities to develop communication skills, thinking, problem solving, and using life skills, and use of technology, and

6) School activities will focus on activities that enhance competency and learning, consisting of 5 activity groups.

Step 3: Aspect to strengthen characters and values is;

1) An activity to instill in students to become more patriotic, religious and monarchical,

2) The students enjoyed the activities,

3) The organization of activities is essential to the daily life of the students,

4) Cultivate consciousness and values to benefit society, have a public mind and use of various services, both for the benefit of ourselves and the public, cultivate patriotism, religion, and the monarchy, and cultivate morality, ethics, and good conduct towards students.

5) 12 values strengthening, and

6) Strengthening of characteristics and values consists of 4 groups of activities.

Step 4: Enhance working, living and life skills

1) Activities to respond to interests and aptitude,

2) Student life promotion activities,

3) Activities to meet the needs of learners according to their differences,

4) Integrate learning experience with lifestyle, have life skills, work with others, love and unity of working in a group,

5) Enhancing working skills, the lifestyle that the executives and teachers must organize activities that students can use in their daily life. Each activity has to be repeated and always focused on review so that students do not forget the activity, and

6) Strengthening of working, living and life skills consists of 4 groups of activities.

Create a series of activities to reduce the study time, increase the learning time of primary school students.

Step 1: Learning management is the first activity set, the learning management is

Activity 1: Thai tells stories

Activity 2: Finding a partner

The second area to enhance competency and learning is the second set of activities to enhance competency and learning, namely

Activity 1: A little scientist

Activity 2: Math, think fun.

Set 2 to strengthen characteristics and values is the third set of activities to strengthen characteristics and values.

Activity 1: Learn about history through a movie screen

Activity 2: Support religion.

The fourth area enhances working skills, livelihoods, and life skills, which is a set of 4 activities to strengthen characters and values, namely

Activity 1: Aerobics to excellence

Activity 2: Organic Agriculture (Agriculture)

\section{Discussion}

The research findings can be discussed as follows:

1. The results of the study, the format of the activities to reduce the study time, increase the learning time of the students at the basic education level according to the government policy, found that the opinions of all four aspects of students were at a high level, namely

Part 1: Learning management, there is a high level of overall practice, i.e. students learn to coexist, considerate and help each other. Students learn and practice happiland develop their own abilities.

Part 2: Enhancing competencies and learning, there is a high level of overall practice, including activity patterns that meet the needs of students. The media / materials used for the activity are appropriate. The duration of the activity is appropriate.

Part3: Strengthen characters and values, there was a high level of overall practice, including activities to cultivate students to become more patriotic, religious and monarchical. The students enjoyed the activities and organizing activities is essential to the daily life of the students.

Part 4: Enhance working, living and life skills, the overall practice level was at a high level, including interest response activities, aptitude, student life promotion activities, activities meet the needs of learners according to their differences, and corresponding to the research results, the format of activities to reduce the study time, increase the knowledge time of the students at the basic education level according to government policy.

In line with Ket Amon's Mingkhaowhas' study of "Conditions and problems according to the policy to reduce school hours Under the Office of Ubon Ratchathani Primary Educational Service Area 4", the research found that the condition and problem of implementation of the policy to reduce school hours in overall practice was at a high level. [6]

And in line with PornthipTaosuwan's research in "Evaluation of the teaching and learning process of primary school teachers: a case study of primary school teachers in Yala Province", the research results were found that 4 factors related to the teaching and learning process the evaluation side informs the students about the evaluation criteria and has prepared the teaching, review and understand the content before the exam. There is a continuous connection of teaching and teaching materials. [7]

2. To develop activities to reduce learning time and increase learning time of primary school students.

Section 1: Learning management includes thoughtful students and helping each other to learn happily, practice and develop, increase one's abilities. Integration to complete $4 \mathrm{Hs}$, namely Head, Heart, Hand, and Health, and the learning time reduction activities of the Office of the Basic Education Commission set out 4 sections, 16 groups. The four sections include 1) learner development activities, 2) building activities, enhance competence and learning, 3) Strengthen characters and values, and 4) Strengthen working skills, livelihoods and life skills.

Section 2: Enhance competency and learning, i.e. activities that respond to student needs. The media / materials used for the activity are appropriate. The duration of the activity is appropriate. The school focuses on organizing activities to enhance competencies in 5 areas, including communication, thinking development, problem solving, use of technology, and life skills development. 
Section 3: To strengthen the characters and values, it includes activities to instill students to become more patriotic, religious and monarchical, and to have fun in doing activities. Organizing activities are essential to the daily life of the students, cultivate consciousness and values to benefit society, have a public mind and use of various services, both for the benefit of ourselves and the public, cultivate patriotism, religion, and the monarchy, and cultivate morality, ethics, and good conduct towards students with 12 values strengthening characteristics and values Strengthening.

Section 4: Strengthening work skills, livelihoods, and life skills, including interest-response activities, aptitude, student life promotion. Activities meet the needs of learners according to their differences, integrate learning experiences with lifestyle, life skills, work with others, love and unity of working in a group, and building work skills. For the lifestyle that the executives and teachers must organize activities that students can use in their daily life, each activity has to be repeated and always focused on review so that students do not forget the activity. The enhancement of working skills, living and life skills consisted of 4 groups of activities, development activities, reducing learning time, increasing learning time for students at basic education level according to government policy.

In accordance with Sukanya Phuphuekok, it was found that the teaching and learning management is linked to the natural community and environment. Practice thinking, practicing, self-assessment and self-improvement, encouraging students to learn happily and successfully, and standard 6 organizes teaching and learning by cultivating morals, ethics and good traits and practicing them into habits.[8]

3. Create a series of activities to reduce learning time to increase the learning time of primary school students as follows:

The first area of learning management is activity series 1, learning management, namely activity 1: Poh Pong telling stories, activity 2: Finding a partner

The second area to enhance competency and learning is the activity series 2 to enhance competence and learning, i.e. Activity 1: Little Scientist, Activity 2: Fun Math.

The third aspect to strengthen character and values is activity series 3 to strengthen character and values, i.e. activity 1: Learn history through a movie screen, activity 2 : Support religion.[9]

The Section 4 to strengthen working skills, livelihoods and life skills is the activity package 4, enhancing characters and values, namely Activity 1: Aerobics to Excellence, Activity 2: Organic Agriculture (Agriculture) with the aforementioned research results consistent with Jareerat Panprommin having studied the activities of students. It was found that the overall teaching and learning activities and activities were at a moderate level. Organize teaching and learning activities in circles and outdoor play activities.[10]

\section{Recommendations}

\section{Recommendations for Practices}

The results of this research with suggestions and opinions of the experts, both administrators and teachers, who are expertise and experienced in learning time reduction and learning time, including

1. The relevant departments or schools should provide an environment that facilitates student learning, both inside and outside the classroom.

2. Relevant agencies should promote budget support for schools to organize activities to reduce learning time, increase learning time.

3. The relevant departments should arrange the content of the activities according to the age of the students.

4. Relevant agencies should organize activities to enhance physical performance for primary school children because it is an age with good physical development and growth.

\section{Recommendations for Further Research}

1. A study of development strategies, reduction of learning time, increasing learning time for teaching and learning management at basic education level.

2. A study of activities that reduce learning time and increase learning time for teaching and learning management at the basic education level.

\section{Conclusion}

Conclusion of the research on learning management to help students learn to integrate to complete $4 \mathrm{H}$, namely Head, Heart, Hand, Health Sport Day. To enhance competency and learning to focus on organizing activities to enhance 5 aspects of character enhancement, and 12 values to promote working skills, livelihood and life skills, including interestresponse activities, aptitude, activities promoting students' livelihoods. Activities meet the needs of learners according to their differences, integrate learning experiences with lifestyle, life skills, work with others, love and unity of working in a group. Building work skills the lifestyle that the executives and teachers have to organize activities that students can use in their daily life each activity has to be repeated. They always focus on review so that students do not forget the activity. The enhancement of working skills, livelihoods and life skills consists of 4 groups of activities through activity for excellence..

\section{References}

[1] Wanchai Yingrungruang, the teachers' opinions on organizing the activities "Reduce learning time, increase learning time" in the school group of compulsory secondary schools, Prasat District, Surin Province. Master of Education Thesis Educational Administration Surin Rajabhat University, 2017.

[2] Sipanon Ketutat. "Education Policy : Teachers, administrators of education and globalization ". Teacher civil service journal. 16 (February - March 1996): 96. 
[3] Office of the National Primary Education Commission Path to Success in Implementing Thai Education Policy: Ministry of Education's Educational Reform Implementation Guide (Bangkok: Office of the National Primary Education Commission, 1999),

[4] Office of Academic and Education Standards, Office of the Basic Education Commission, Ministry of Education, Study Time Management Manual "Reduce learning time, increase learning time" (Duplicate document)..

[5] Yupharet Khao Chum "Development of a learning management process based on the concept of Teach Less. Learn more by using online teaching materials in conjunction with normal teaching." Master of Education Thesis Department of Educational Technology and Communication Faculty of Industrial Education Rajamangala University of Technology Thanyaburi. 2016.

[6] Prawit Pramarn, an activity model to "reduce learning time, increase learning time" in education fund schools. In Phra Nakhon Si Ayutthaya Province Master of Education Thesis Department of Physical Education Phranakhon $\mathrm{Si}$ Ayutthaya Rajabhat University, 2016.

[7] PorntipTaosuwan, Teaching and Teaching Assessment of Primary Education Teachers: A Case Study of Thesis Primary Teachers, Yala Province: Ministry of Education, 2000.

[8] Sukanya Phupuengkhok. "Implementation of Teaching Standards under Educational Quality Assurance Policy in Primary Schools, Loei Province", Master of Education Thesis, (Graduate School: KhonKaen University, 2002),

[9] Jutamas Suthapot Guidelines for the management of learning activities in accordance with the policy of "reduce study time, increase learning time" of basic schools. Under the jurisdiction of Nonthaburi Provincial Primary Educational Service Area Office 2 Master of Education Thesis Education: Academic degree: Suan Sunandha Rajabhat University, 2016.

[10] Jareerat Panprommin. "Education and performance in teaching and learning activities of pre-primary teachers under the Office of Primary Education, Krabi Province". Master of Education Thesis, Graduate School: Thaksin University, 2004. 